\title{
CONSERVING THE PALESTINIAN ARCHITECTURAL HERITAGE
}

\author{
JIHAD AWAD \\ Architectural Engineering Department, Ajman University of Science \& Technology, United Arab Emirates.
}

\begin{abstract}
Despite the difficult situation in West Bank, the Palestinians were able to, during the last three decades, preserve a huge part of their architectural heritage. This is mainly due to the notion that this issue was considered as an essential part of the struggle against occupation and necessary to preserve their identity. This paper will concentrate mainly on the conservation efforts and experience in West Bank, Jerusalem, and the Gaza Strip. It covers not only examples from major cities but also some important ones in the villages. Due to the special situation of being occupation, and the absence of a central authority responsible for heritage conservation, several entities were established and became involved in conservation, with diverse goals and approaches. Although it started during the last three decades, the Palestinian experience in conservation has received international recognition for some distinguished successful examples. It became in some cases a good reference for others outside Palestine. The main goal of this paper is to present the Palestinian experiment in conservation and to highlight the reasons behind the successful examples and find out the obstacles and difficulties in other cases. It shows that for the Palestinians preserving the architectural heritage became a part of their cultural resistance and efforts to maintain their national identity. This paper depends on a descriptive method based on publications and some site visits, in addition to direct contact with major institutions involved in heritage conservation in Palestine.
\end{abstract}

Keywords: conservation in Palestine, Heritage conservation, Palestinian architecture, Palestinian heritage.

\section{INTRODUCTION}

During the last three decades there has been an increasing awareness for preserving the architectural heritage in all Palestinian areas, in West Bank, East Jerusalem, and the Gaza strip, as part of a more general trend to emphasize and maintain the national Palestinian identity.

Despite the difficulties and challenges due to the occupation, and despite the absence of a national authority responsible for conserving the architectural heritage, with lack of governmental support and resources as well as the absence of private investors, conservation projects are to be found in almost all Palestinian cities and villages, ranging from one single object to a large area conservation, in urban as well as rural sectors.

The conservation issue for the Palestinians has a political dimension and became part of their culture, not only in architectural but in many other fields too.

The culture of conservation is reflected through many examples from different Palestinian areas, urban and rural, small buildings and area conservation, carried out by different institutions and committees. 


\section{CONSERVATION IN MAJOR PALESTINIAN CITIES}

\subsection{The old city of Jerusalem}

The old city of Jerusalem, which is part of what is called East Jerusalem, along with the West Bank, remained under the Arab administration from 1948 until 1967, when the Israelis annexed the whole city. The old city of Jerusalem is like a huge museum for historical buildings from different periods and styles. Despite the difficult circumstances and restrictions, the old city is still intact and maintains its original identity.

Since 1967, the majority of original inhabitants have left their homes and moved to new areas in or outside Jerusalem. This was due to policies aimed at forcing the Palestinians to leave their original homes. The result was more deterioration, especially with policies that made it almost impossible for Palestinians to restore or repair their own homes.

During the eighties of the previous century, some limited restoration works were completed by the Supreme Islamic Council, the Islamic Waqf department, and some churches. These works concentrated mainly on the Haram area (Aqsa Mosque and Dome of the Rock), in addition to other religious buildings. Later on, many other institutions became involved in restoration work, and they expanded their activities to involve other types of buildings as well as residential areas. They were later unified under the name 'Jerusalem Rehabilitation \& Development Committee,' which was responsible for restoring and maintaining more than a hundred houses [1].

\subsubsection{Welfare association}

The most important and comprehensive plans for conserving the cultural heritage of the old city of Jerusalem are prepared and implemented by the Welfare Association (Mo'ssasat Al Ta'awun), which started a restoration programme in 1994, supported by the Arab Fund. In 1998, a special team of experts was formed to prepare a revitalization plan for the old city. The plan aims at protecting, maintaining, revitalizing, and developing the old city, physically, socially, and economically [2].

The goals of the plan can be summarized as follows:

- To terminate the physical and social decay or deterioration.

- To improve the living conditions and create appropriate urban environment.

- To maintain originality while ensuring today's living requirements and needs.

- To retain or revive the central role, socially and economically, of the old city, and bring back people of middle- and high-income residents, and make the old city attractive for investors and visitors.

- To stop the expansion of Israeli settlements inside the old city, through increasing the original Palestinian inhabitants, without affecting the cultural heritage.

- To increase the public awareness of the importance of revitalizing the old city and ensuring to maintain it in the future.

In 2004, the Welfare Association received the Aga Khan Award for Islamic Architecture for its efforts in Jerusalem. One of the largest and important projects restored as part of the plan is the Orphans House (Fig. 1) [3]. 

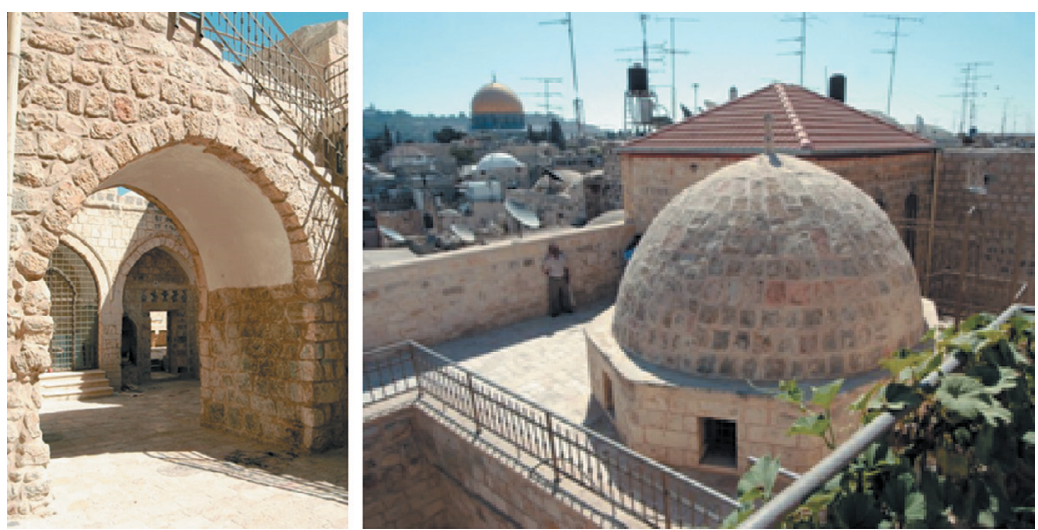

Figure 1: Dar al-Aytam al-Islamiya (Orphans House), Jerusalem [3].
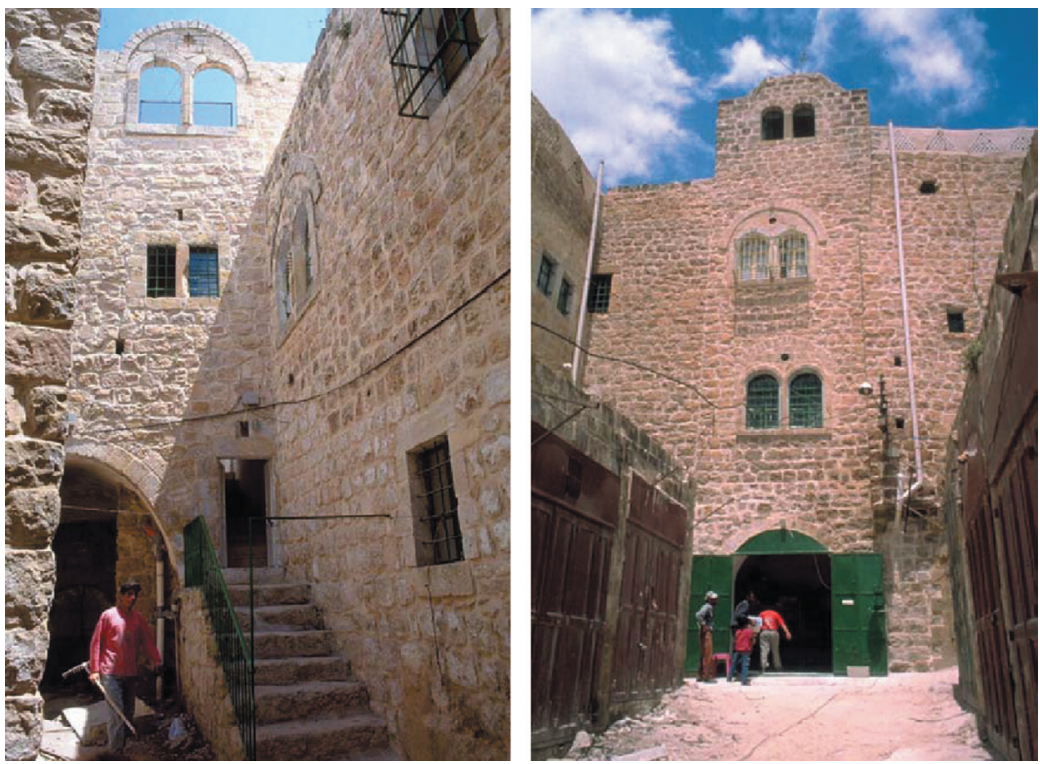

Figure 2: The old city of Hebron [6].

\subsection{The old city of Hebron}

After Jerusalem, Hebron is the only Palestinian city that has Israeli settlers inside its old city. Under enormous pressure most of the original Palestinian residents were forced to leave their houses from 1967 (Fig. 2). As a result, in 1996, the Hebron Rehabilitation Committee was established to:

- Maintain the cultural heritage and pass it on intact to future generations.

- Emphasize the Arab character of the old city and retain normal life in it.

- Stop the migration of Arab families from the city and bring new people to it.

- Prevent settlers from expanding in old city [4]. 
The main policy here depends on solving the ownership problem. The committee is trying to revive the old city and draw the population back. When the buildings are restored, the families who own them will either move back in or will rent them to local families with the Hebron Rehabilitation Committee acting as an agent, according to agreement with the original owners. In 1998, the project received the Aga Khan Award for Islamic Architecture for its efforts [5].

\subsection{The city of Bethlehem}

In most historic areas of the city, the United Nations Development Programme (UNDP), in cooperation with the Palestinian Ministry of Tourism and Antiquities, rehabilitated streets, arches, facades, and infrastructure (Fig. 3). The project was made possible by a grant from Japan as part of the preparations for project Bethlehem 2000. Restoration activities were not only targeted at beautification of the area. These projects are not just for rehabilitation but to ensure that people can live here [5]. The projects are attentive to the modern-day needs of the local residents without losing sight of preserving the historical character of the urban fabric.

\subsection{The old city of Nablus}

The old city of Nablus has suffered, probably more than any other Palestinian city, from the massive invasion by Israeli forces during the second uprising which started in 2000. Many restoration projects were previously completed by the municipality but unfortunately destroyed by the Israeli bombing of the old city. Many buildings were heavily damaged by Israeli rockets during April 2002. A project was carried out by UNDP and funded by the Japanese government to rebuild the houses. Then in December of 2003, many houses were again damaged during Israeli military activity [5]. This kept recurring: buildings were repaired and then damaged. Some of the projects are now in progress supported by European and Japanese governments. One of these projects is the revitalization of the Khan Al Wakalah (Fig. 4). The

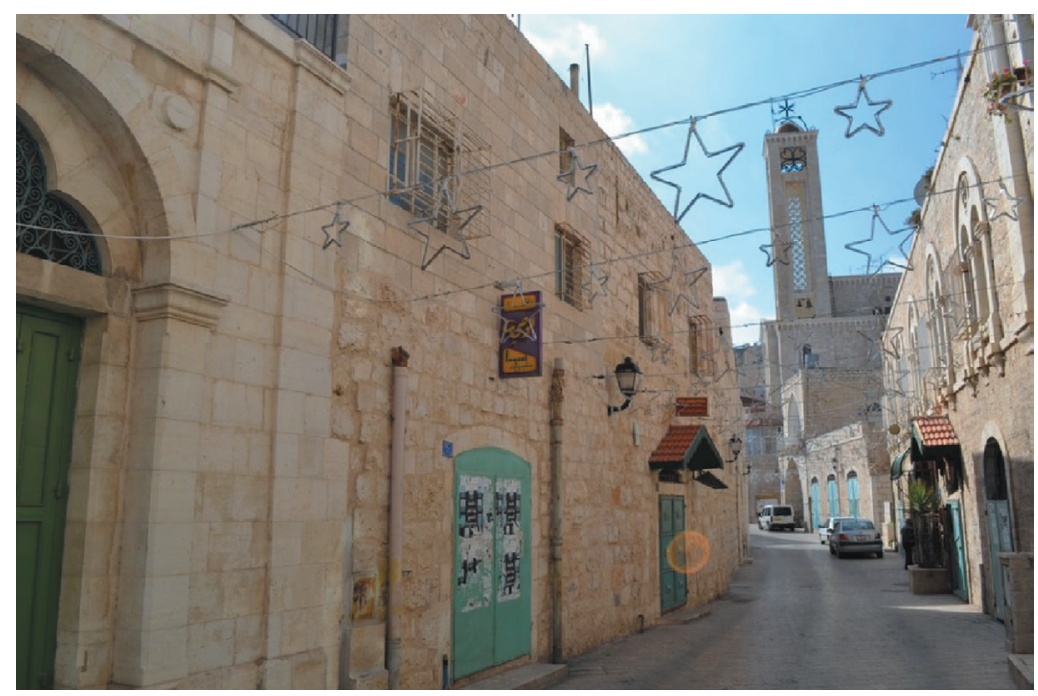

Figure 3: Star Street, Bethlehem [7]. 

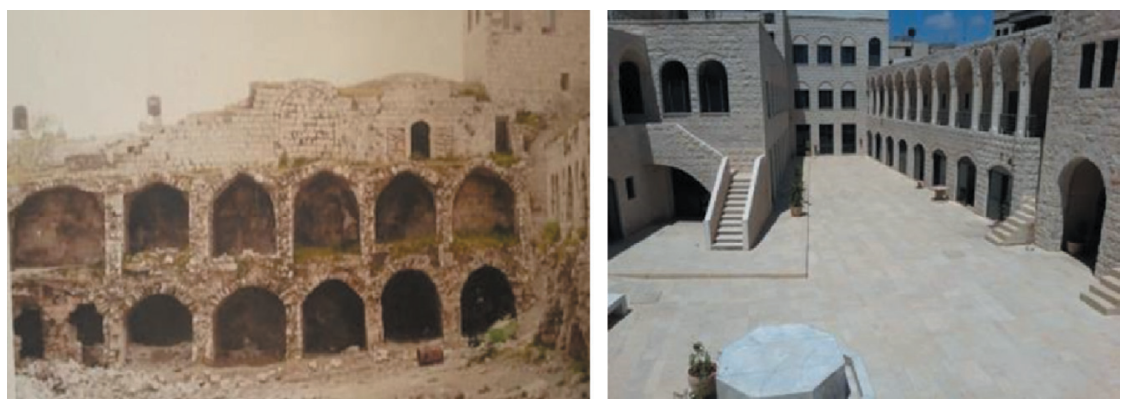

Figure 4: Wakala Farroukhiyyah, Nablus.

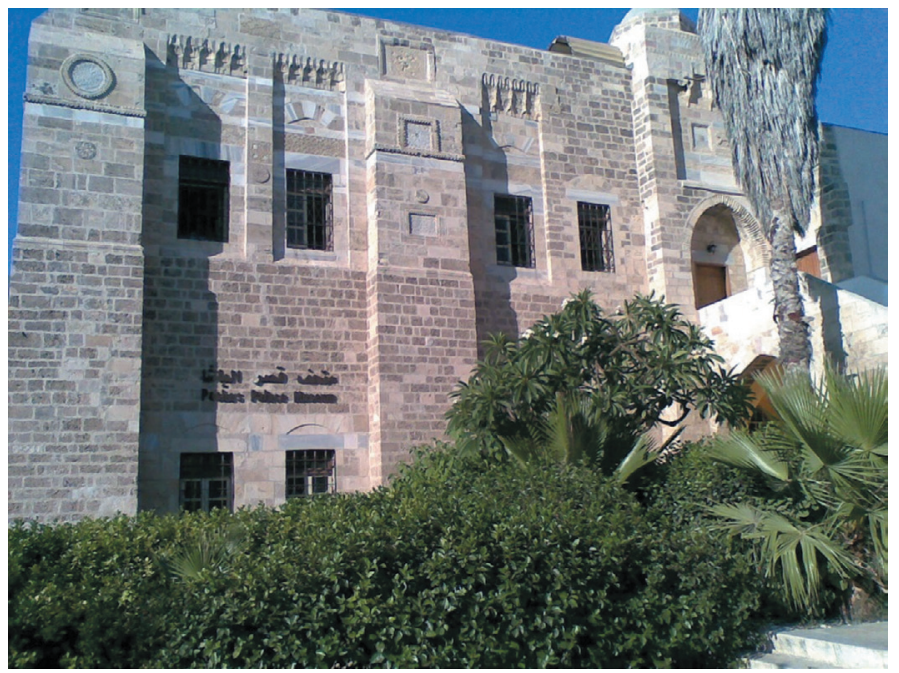

Figure 5: Al-Pasha Palace Museum, Gaza [10].

Khan Al Wakalah project is part of a Euro 5 million EU-funded programme, implemented by UNDP in cooperation with the Ministry of Tourism and Antiquities, local communities and other relevant stakeholders in the tourism sector. The programme aims at supporting the development of cultural tourism through the engagement of the private sector through PublicPrivate Partnerships. This project is strongly integrating cultural heritage and socio-economic development. It is worth noting that the main rehabilitation works of Khan Al Wakalah were completed in 2012 through another EU fund executed by UNESCO [8].

\subsection{Gaza city}

The architectural heritage in Gaza suffers from different dangers that threaten its existence. Local parties concerned with the protection of historical buildings have succeeded in renovating some important buildings, such as Al-Omary Mosque, Hammam Al-Samara and Pasha Palace [9]. One of the most important heritage institutions in Gaza is the IWAN Centre for Architecture Heritage, which cooperates with international associations, such as UNESCO and UNDP (Fig. 5). 


\section{INSTITUTIONS INVOLVED IN PRESERVING CULTURAL HERITAGE}

During the last three decades, several institutions and organizations became more involved in preserving the Palestinian architectural heritage. The major heritage centres and associations are: RIWAQ Centre for Architecture Conservation; the Hebron Rehabilitation Committee; the old city of Jerusalem Revitalization Program (part of the Welfare Association); the Centre for Cultural Heritage Preservation (Bethlehem); the Mosaic Centre of Jericho; the Nablus Civilian Committee; and IWAN Centre for Architectural Heritage in Gaza. Most of these entities are city-based institutions operating at the local level, and they have concentrated their efforts in specific localities, except for RIWAQ Centre, which has been working in all Palestinian areas.

\subsection{RIWAQ centre for architectural conservation, Ramallah}

Established in 1991, with the purpose of protecting and developing Palestinian architectural heritage, RIWAQ has acted as a 'catalyst for ideas' and has consequently set the model for heritage conservation as development in Palestine. Contrary to similar heritage organizations, RIWAQ operates across the West Bank and Gaza and has focused on the rehabilitation of historic buildings for public use in towns as well as in villages, but focusing mainly on cultural centres. 'Since 1991, RIWAQ has recognized the challenging complexities of preserving Palestinian collective memory through projects that document and restore architectural heritage sites across the West Bank and Gaza' [11]. RIWAQ was the first organization to develop, in cooperation with municipalities, protection master plans for the management of historic towns and villages with the purpose of integrating heritage protection with urban development [12]. In addition, RIWAQ has organized numerous training workshops, launched campaigns, and published several books and monographs on various aspects of the Palestinian cultural heritage. RIWAQ embarked on the Registry of Historic Buildings, a thirteen-year project (1994-2007) resulting in the publication of three volumes that include detailed histories, maps, and photos of approximately 420 villages in sixteen districts across the West Bank, Jerusalem, and Gaza. RIWAQ's 'Job Creation through Conservation' has transformed cultural heritage into an important economic tool, and it has shifted the concept of architectural conservation from an activity exclusive to the affluent to one that provides skill-building opportunities for residents and community economic development for neighbourhoods, villages, and municipalities [11]. Recently, RIWAQ has shifted its priorities and resources from the conservation of single historic buildings to a universal approach that engages entire communities. It has succeeded in responding to the vital question of what it takes to rehabilitate an entire town, not only physically but socially, culturally, and economically. RIWAQ's approach is not just to restore the historic centres but also to see how restoration is going to help communities to develop. Below are some examples of historic buildings, in villages and towns throughout the West Bank which have been rehabilitated by RIWAQ and turned into community or cultural centres (Figs. 6-9):

\subsubsection{Revitalisation of Birzeit Historic Centre}

The Revitalisation of Birzeit Historic Centre, part of a rehabilitation master plan initiated by RIWAQ, received in 2013 the Aga Khan Award for Architecture (Fig. 10). This five-year project has transformed the decaying town of Birzeit, has created employment through conservation, and has revived vanishing traditional crafts in the process. Community involvement was encouraged from the start: including local NGOs, the private sector, owners, tenants and 

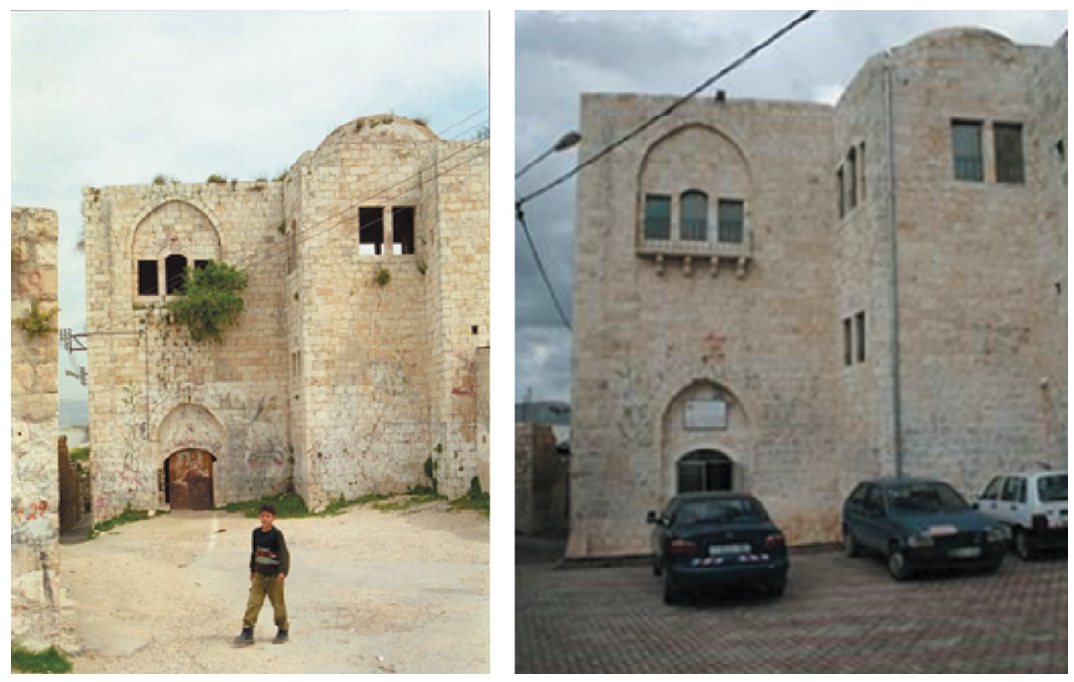

Figure 6: Al-Qasem Palace, Beit Wazan, Nablus [RIWAQ].
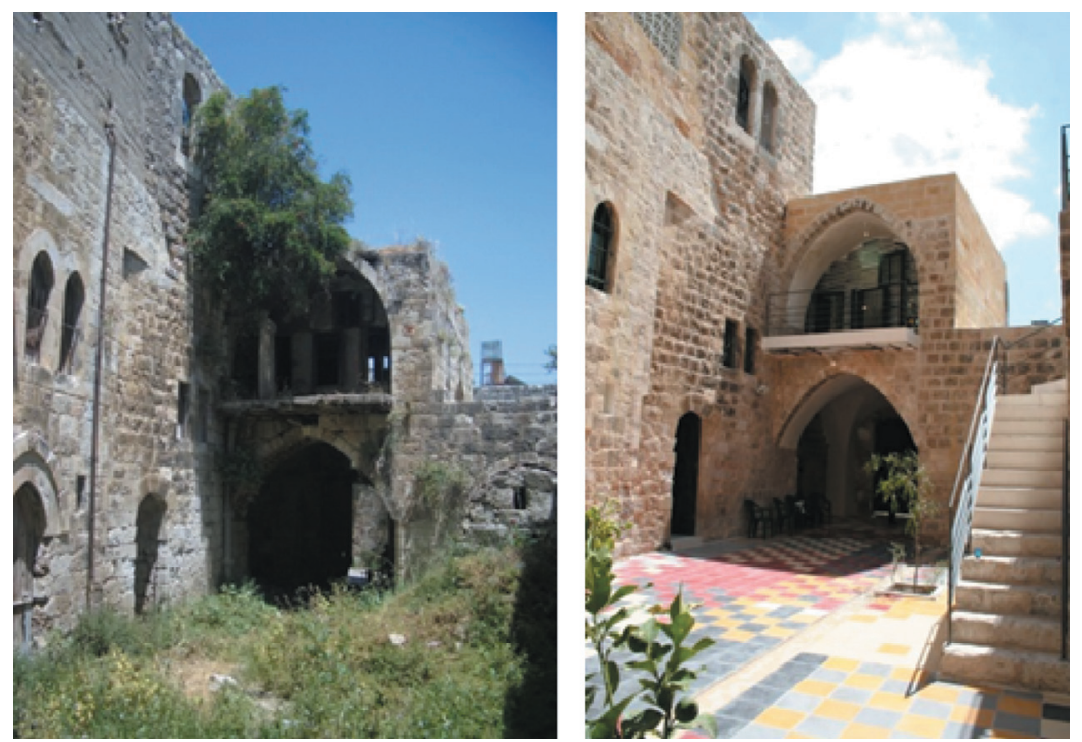

Figure 7: Al-Kayed Palace, Sebastia [RIWAQ].
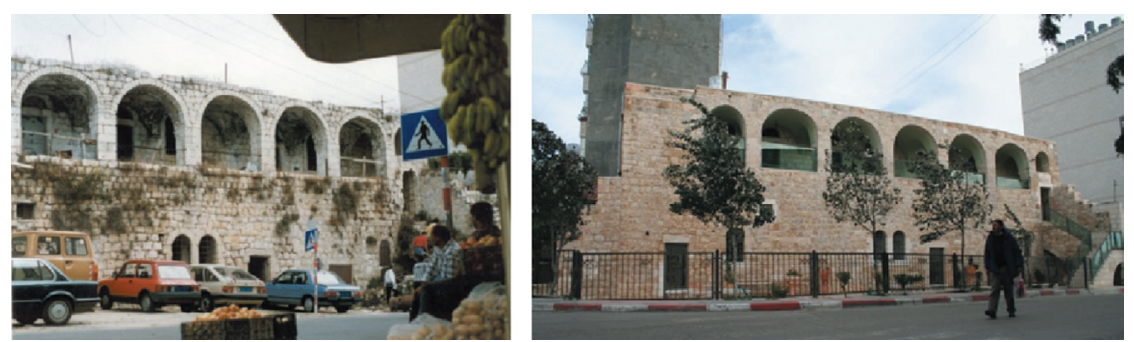

Figure 8: The Ottoman court, Ramallah [RIWAQ]. 


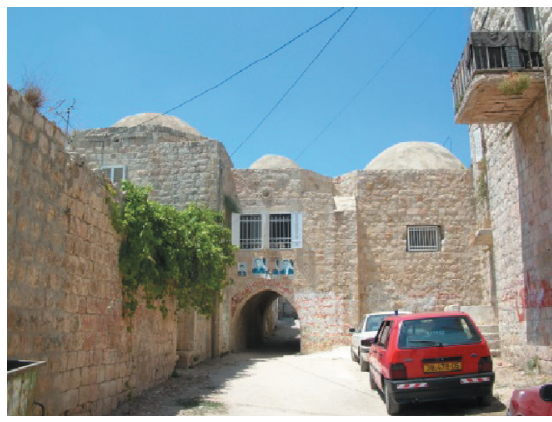

A: Deir Ghassaneh

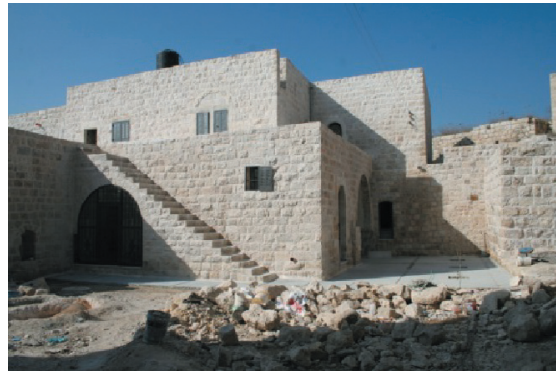

C: Ras Karkar

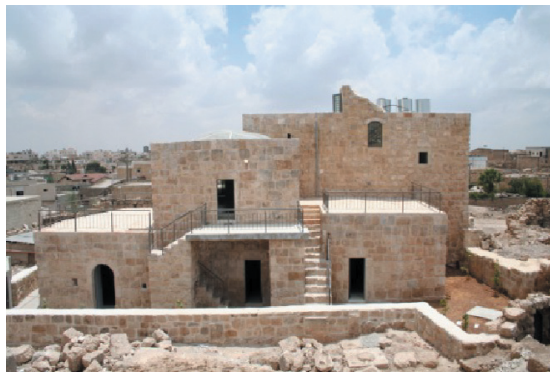

E: Al Thaheriyya

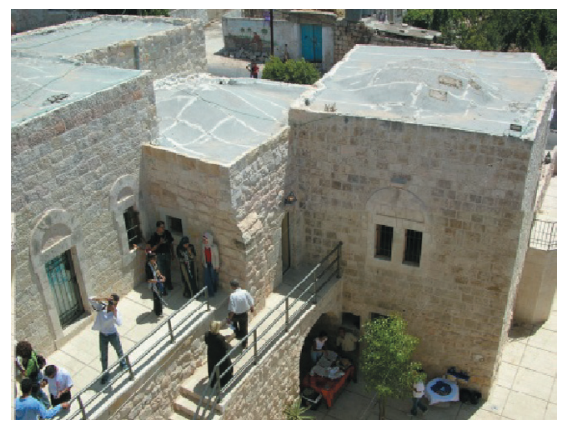

B: Beit Reema

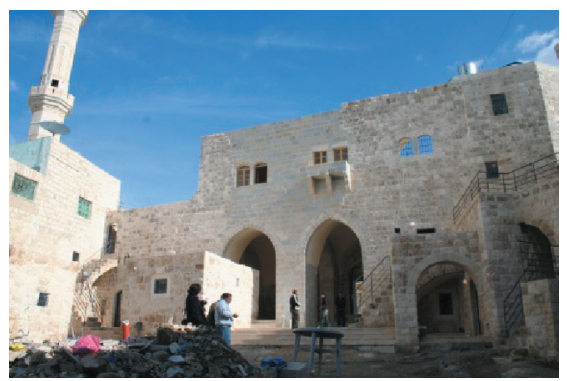

D: Al-Khawaja Palace

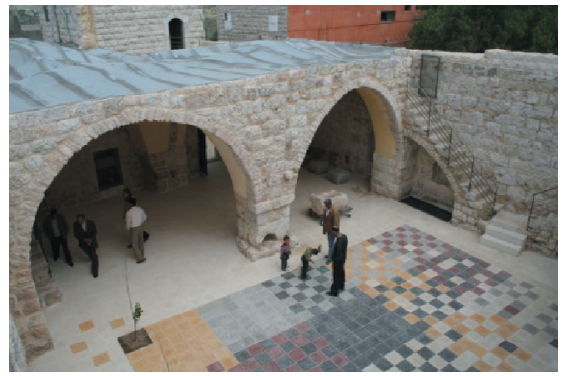

F: Bruqin - Salfit

Figure 9: Projects by RIWAQ in different villages.

users, all working with the municipality. Both historic buildings and public spaces have been rehabilitated into community activity hubs [13]. The Revitalisation of Birzeit Historic Centre is a dynamic project in which RIWAQ succeeded in mobilizing stakeholders and local craftsmen into a process of healing that is not merely physical but that is social, economic, and political. By reversing a process of neglect and erasure within a complex and difficult political context, the project managed to transform not only a neglected historic core but also people's lives, and it restored not only buildings but the dignity of their users. The project offers an alternative to 'museified' historic cores and it pioneers the regeneration of Birzeit's historic centre into cultural infrastructure. It facilitates the reclamation of heritage by the people involved while also allowing them to achieve their self-expressed aspirations. The project is an exemplary dedication to rural heritage that can serve as a model for the 50 villages in which RIWAQ is involved, particularly the strategic interventions designed to stimulate longterm development (Citation from the Jury of The Aga Khan Award for Architecture) [14]. 


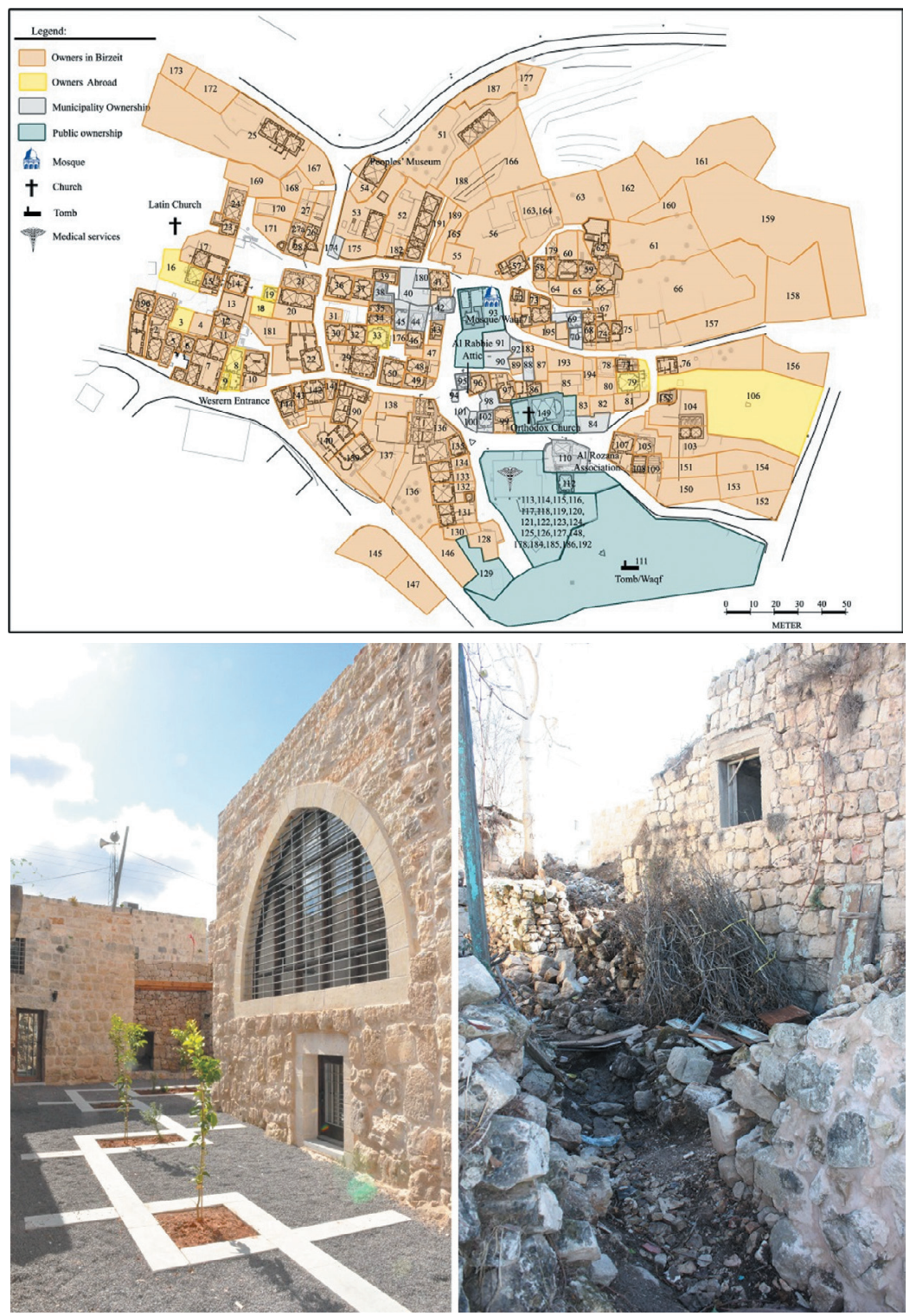

Figure 10: Revitalisation of Birzeit Historic Centre [13].

\section{CONCLUSIONS AND RECOMMENDATIONS}

The increasing number of conservation and restoration projects all over the Palestinian areas shows clearly the increased public awareness for protecting and preserving the architectural heritage. Palestinians consider maintaining architectural heritage as one form of cultural struggle against the occupation in order to emphasize their national identity. The idea of heritage preservation as a national duty became a feature of Palestinian heritage.

After studying and analysing these conservation efforts by various institutions and organizations, some points need to be taken into consideration in future: 
- There is an urgent need for a national authority responsible for conserving the architectural heritage.

- Cooperation and coordination between different organizations involved in conserving the architectural heritage are needed.

- Training courses and workshops; site visits and trips to heritage areas; and educational programmes are required and need to be developed.

- There should be support programmes and initiatives to encourage and educate people to enable them to take part in preserving the cultural heritage, and to provide necessary assistance to prevent deterioration.

- There is a need to develop proposals and initiatives to ensure future and sustainable maintenance with minimum dependence on aids and donations by supporting countries and agencies.

- Mutual cooperation and exchange of experiences and information with international organizations should be increased.

- A legal regime for the protection of cultural heritage is urgently required.

\section{REFERENCES}

[1] Sandouqah, H., The City of Jerusalem - Rehabilitation Projects for the Old City (in Arabic), pp. 19-22, (no date). Jerusalem. (Technical report to Awaqaf).

[2] Welfare Association, Jerusalem: Heritage and Life - The Old City Revitalisation Plan, pp. 9-12, 2002. Welfare Association, Jerusalem.

[3] Old City of Jerusalem Revitalisation Programme, available at: http://www.akdn.org/ architecture/project/old-city-jerusalem-revitalisation-programme (accessed 10 June 2016).

[4] Hebron Rehabilitation Committee, Achievments and Ambitions (in Arabic), 1999. Hebron Rehabilitation Committee (HRC), Hebron.

[5] Focus, UNDP/Programme of Assistance to the Palestinian People, Vol. 1, pp. 16-24, 2004, available at http://www.undp.ps/en/newsroom/publications/pdf/focus/04v1.pdf

[6] Conservation of Hebron Old Town, available at: http://archnet.org/sites/1425 (accessed 10 June 2016).

[7] Star Street, Interventions, Improving of Street Light Network, available at: http://www. starstreet.ps/en/interventions/improving-of-street-light-network (accessed 10 June 2016).

[8] The European Union and UNDP support Nablus Municipality in revitalizing Khan Al Wakalah site, available at: http://www.ps.undp.org/content/papp/en/home/presscenter/ pressreleases/2015/12/07/the-european-union-and-undp-support-nablus-municipalityin-revitalizing-khan-al-wakalah-site-.html (accessed 10 June 2016).

[9] Al-Qeeq, F., A comprehensive approach to incorporate architectural heritage of Gaza Old City into contemporary urban fabric, p. 9, 2011, available at http://www.cpasegypt.com/

[10] http://www.d44.co.il/news.aspx?cid=195\&aid=9576

[11] RIWAQ - Our Story, available at: http://www.riwaq.org/our-story (accessed 10 June 2016).

[12] Chiara De Cesari, Cultural heritage beyond the 'state': Palestinian heritage between nationalism and transnationalism, PhD, Stanford University, pp. 125-126, 2008.

[13] Revitalisation of Birzeit Historic Centre, available at: http://www.akdn.org/ Architecture/project.asp?id=4022 (accessed 10 June 2016).

[14] RIWAQ - Awards, available at: http://www.riwaq.org/awards (accessed 10 June 2016). 